\title{
The Islamic Basis For Mutual UNDERSTANDING IN INTERCULTURAL COMMUNication
}

\section{Hasan Yousefzadeh}

Al-Mustafa International University, Qom, I.R. Iran

\begin{abstract}
Intercultural philosophy has been recently incorporated as an interdisciplinary field into the Western academia. Intercultural philosophy strives to present a way of thinking for the development of the "culture of dialog" among cultural units, aiming at bringing about the novel potentials of understanding, will, and wisdom of the crowd as solutions to the issues of the modern man as well as his progress and transcendence. Intercultural thought is not simply a theoretical and philosophical hypothesis, but it serves as a scientific strategy and a means of breaking philosophical and cultural deadlocks whereby people, despite enjoying "change", do not necessarily regard "others" as threatening or adversaries to the "insider's" identity. The present study, applying a descriptive and interpretive methodology, aims to address the question of the degree to which intercultural philosophy is commensurate with Islamic thought and the nature of mechanisms provided from the Islamic perspective (the Holy Quran) for mutual understanding and overcoming the current deadlocks. This study concludes that the Islamic perspective, inspired by the verses of the Holy Quran and the Sunna of the Infallible Imams, provides the modern man with, at least, three bases for mutual understanding: Islam whose laws are applicable to the Islamic society; potentials shared by religions; human innate nature ( $\mathrm{fi}$ tra). These three bases actually tend towards monotheism. In short, it is but through a recourse to the potentials of religions that the modern man may succeed in finding solutions to social and epistemological crises.
\end{abstract}

Keywords: Intercultural communication, mutual understanding, human innate nature, fitra, islam

Corresponding author: usefzadeh.h@gmail.com 


\section{Intercultural Philosophy}

In recent years, intercultural philosophy has found its position in Western countries as an academic discipline. Among the scholars, Mall, Wimmer, Kimmerle and Betancort have attempted to define and explain the structure of intercultural thought more than others (Razavirad, internet).

Intercultural philosophy seeks to provide a way of thinking about developing a "culture of dialog" among cultural units, in order to develop new capabilities for understanding the collective wisdom and the will to solve contemporary human problems. The culture of dialog within itself emphasizes the reality of pluralism in perceptions, attitudes, rituals, customs, and a lack of bias in dealing with other ideas and opinions, as well as justice and respect for the "other". As we can see, the basic principles of intercultural philosophy are a dialogue and some interrelated characteristics called tolerance (Shah Hoseini, internet).

It is believed that intercultural thought, despite being inspired by the inefficiencies and shortcomings of the West, is not Western, because the West confronts intercultural thought with challenge and hate. This thought removes transculturalism and lightculturalism, which is a hidden and obvious claim of the West. Perhaps because of this, the intercultural philosophers in the West, especially in Germany, have not yet been accepted and they face many problems. (Razavirad, ibid.)

Some of the main figures of intercultural thought, such as Mall and Betancort, are not essentially Western, and if Kimmerle defends intercultural thought, he considers it to be the product of more than 20 years of study and presence in Africa! Of course, it cannot be said that the westerners do not like or do not want to employ "intercultural thought", but it should be emphasized that, with the continuation of the absence of others, in the context of the world's intellectual and cultural transformations, they will, of course, employ it more easily. Intercultural thought focuses on the presence of "others", and this does not have a good message for Western culture, which claims to be the "dominant culture" (ibid.).

It seems that intercultural thought is not a mere theoretical philosophical hypothesis, but a scientific strategy for the overcoming philosophical and cultural deadlocks, so that human beings, despite undergoing a "transformation", do not necessarily consider the "other" as a threat or an enemy of "self" identity (ibid.). The prefix "inter" in the term "intercultural" is not a decorative prefix, but it has specific meaning. If so, and "If we consider the intercultural insight as a philosophy for understanding and exchange among cultures, then the first and most important question is the question of the goal of this course. The goal is communication" (Bolkhari 2013). 
The solution proposed by these theorists to achieve that goal is by realizing a horizontal view instead of a pyramidal or vertical view. It means: "You are the rightful owner of me as well". In the conception of the intercultural philosophy from the dialog, "we regard the other as ourselves, and we consider a symmetrical relation between ourselves and the other. We do not consider our relation with the other vertically" (Mosleh 2007).

One of the characteristics of dialog in intercultural philosophy is tolerance. Because there is a view that in the domain of intercultural communication, it is not multiculturalism (there is a general difference between multiculturalism and interculturalism), but the logic of tolerance that must surely dominate. Tolerance does not mean "tolerating other", but is used in the sense that "we should consider the rights of others as much as of ourselves", and this requires that each group has a more moderate stance towards its worldview and that it sees its ideas bounded, not boundless. From the point of view of these determinants, no context for dialog will be provided until such a space is created (Bolkhari 2013). Mall writes that "intercultural philosophy stands for a process of emancipation from all types of centrisms, whether European or non-European", and that it seeks to exhibit "a philosophical attitude, a philosophical conviction that no one philosophy is the philosophy for the whole of humankind. However, the output of such a view will be relativity in right and truth" (Mall 2000: xii).

Intercultural philosophy has two basic characteristics. One is its philosophical dimension, meaning that it seeks to establish a philosophy that does not have its root in a particular culture, which can be achieved through dialog and communication. Another feature is the condition and the possibility of dialog. Here, some important conditions are considered, including the equal position of the parties in communication. However, they speak less about the real possibility of dialog and basis of communication. And it seems that the reason for neglecting this dimension is a lack of attention that should be given to the divine nature of man and the capacity of monotheistic religions. "The basic argument, as Habermas says, is not power and wealth. He thinks that dialogue can overcome the problems of modernity. There is another fundamental issue that is neglected and it is necessary to pay attention to it" (Mosleh 2007: 174). There is no common element in humans except their humanity. Therefore, intercultural philosophy becomes impractical when this important issue is neglected. Intercultural philosophy has a positive and benevolent attitude, it wants to provide mutual understanding, but it also has problems which it cannot solve, one of the most important of which being "subjectivism". 


\section{Islam and Intercultural Thought}

Intercultural philosophy has similarities and differences with the approach of Islam to intercultural communication. In the Islamic perspective, as is discussed in the light of intercultural thought, there is an attempt to replace "understanding others" with "confronting others". The main point of this idea is that "others" ought not to be slaughtered for the crime of "other" in the forehead of "self" because of "self" and not to be even conceived engaged with it in many cases. Listening to the right words of others is also important. The art of listening should also be taught along with the art of talking and the thought of self should not be considered the end of everything (Razavirad, internet). From the Islamic perspective, communication is not considered longitudinal and pyramidal but horizontal. The term "ta'arafu" in verse 13 of Sura Hujurat elegantly refers to this anthropological point, because "compliment" means a two-way identification. The communicator does not try to prove his comment in any way possible. Instead, by inspiring the divine doctrines, he tries to help to reveal the truth as much as possible. The term "ta'alaw" in verse 64 of Sura Al-i-Imran shows that the speaker, despite being positioned above, speaks in such a way as if he did not rise above the audience and he were in contact with it. The social behavior of the messenger of Allah is mixed with humility and modesty, which makes the word more attractive to the audience and offers conversations based on the horizontal view. But in the pyramid view, a person who is in a higher position considers the audience to be lower than him (Khanmohammadi 2011).

Unlike "intercultural philosophy", the religious and monotheistic rational view will never accept the absolute relativity of rightness and truth. A Muslim always tries to introduce his audience to religion. If "he considers rightfulness and credibility for the other as his own rightfulness and credibility and he never considers the final credit for his viewpoint and opinion", the term "invitational action" will be misleading; in other words, the dialog is not formed just for for the sake of itself. Of course, each dialog follows a predetermined goal. "Usually, everyone believes in his own right and his own way more accurately in comparison with any belief and attitude. The rightfulness of Islam has also been emphasized by the Holy Quran (Al-i-Imran 85 ), and there are solid and rational and narrative reasons in this regard that are considerable; however, in the interaction of Muslims with non-Muslims, or the interaction of groups and different people of each society, if anyone from the beginning argued that he is right and the other party wrong, the path to any dialogue and interaction is closed. The Holy Quran orders the Prophet to tell the polytheists: "Surely, either we or you are rightly guided or in clear error" (Saba 24). The Prophet knew that he is in guidance, but he 
doesn't consider himself to be guided in the discussion with his opponent, but he says that the opposite is the case, one of us is right so that the way of dialogue and ultimately communication can be opened" (Alikhani 2013: 135). Zamakhshari says that the Prophet's speech and this kind of encounter are fair, so the proponent and the opponent who will hear it will say that the speaker is acting fairly. The Quran has ordered the Muslims to say to the religious minorities that "we believe in what has been revealed by God to us and to you" and "our God and yours is one". This means that they themselves and their audiences have the equal status in the conversation (Zamakhshari 1987: V/581). Of course, thoughts about the relatively new phenomenon of intercultural philosophy are not consistent with each other. Razavirad believes that intercultural thought does not relate with the absolutism of cultures; that every culture is necessarily itself, and does not form until it has an Absolutist attitude towards itself. It is important not to refer to absolute self-confidence as other-denial and not to consider "I'm right", necessarily in the meaning of "others are wrong", not to consider the negative and the positive, or commonly known, the black and the white (Razavirad, internet). In his opinion, this idea, without any problem with the absence or presence of absolute truth, doesn't believe in a "unique truth" and sees the truth as "released". According to intercultural thought, the truth is wider and more complicated than the "all or nobody law". This belief should not be interpreted as the "relativity of the truth", which is not a new word; that the truth can be absolute and not at the same time captive in the hands of a certain individual or a particular congregation. This is the meaning of "the released truth". The interpretation of some of the scholars is that intercultural thought aims to somehow replace the humble truth with the biased truth (ibid.).

The point is that some writers introduce real intercultural philosophy into inter-religions' communication. According to them, a real dialogue is possible among religions, because in a postmodern atmosphere in which there is not belief, a dialogue is basically impossible. Farzin Banki uses the term "open discourse" to explain this discussion. Banki has taken the term from Sura of Nasr. In this discourse, instead of a postmodern polyphony, a dialogue between religions or between cultures is being reconsidered. The language of this discourse is fictitious, questionable and inviting. In this discourse, mutual understanding is achieved without any compulsion imposed by personal or collective identities.

An open discourse has taken place not within the boundaries of a communicative society, but within the domain of adjoining communities; nevertheless, it requires the assumption of positions. The existence of two different perspectives and different positions is the condition for the establishment of such a discourse. For example, as long as a Muslim and a Christian are not 
interested in verbal positions and special attitudes, there will not be provided an opportunity for this kind of discourse. In an open discourse, Orientation has its own meaning; here, the acknowledge of its truth is combined with the readiness to accept the transmissions of universal images (Banki 2013: 78-79).

In any case, the advisory in conversation is not new phenomena. There are many teachings in this regard in the Quran and the Prophet's Tradition, and they are referred to in several cases. The Almighty God states: "Therefore give good tidings to my worshipers, who listen to the words and follow what is finest of it. These are they whom Allah has guided. They are those of understanding" (Zumar 17-18). Imam Ali says: "Look at what is told and do not look at whoever speaks" (Amidi 1990: 361). He also says: "Anyone who welcomes other opinions, Knows the error better" (Nahj al-Balaghah, wisdom 173). The traditions that allow receiving wisdom from a pagan (Majlisi 1984: II/97) or a hypocrite (Nahj al-Balaghah, wisdom 80) show that the discourse is to be limited to the Muslim community.

\section{The Basis for Mutual Understanding in Intercultural Communication From the Perspective of the Quran}

At least four verses from the Holy Quran can be chosen as the basis of the topics of intercultural communication from the theoretical and infrastructural aspect, and other related verses might be discussed on the margins of these verses. These four verses are:

1. Invitation verse: "Call to the way of your Lord with wisdom and goodly exhortation, and have disputations with them in the best manner; surely your Lord best knows those who go astray from His path, and He knows best those who follow the right way" (Nahl, 125).

2. Islamic Nation verse: "And surely this your religion is one religion and I am your Lord, therefore be careful (of your duty) to Me" (Mu'minun, 52).

3. Commonalities of religions verse: "Say: O followers of the Book! Come to an equitable proposition between us and you that we shall not serve any but Allah and (that) we shall not associate aught with Him, and (that) some of us shall not take others for lords besides Allah; but if they turn back, then say: Bear witness that we are Muslims" (Al-i-Imran, 64).

4. Recognition verse: "O you men! Surely We have created you of a male and a female, and made you tribes and families that you know each other; surely the most honourable of you with Allah is the one among you most careful (of his duty); surely Allah is Knowing, Aware" (Hujurat, 13). 
Based on the three recent verses, three foundations can be raised for communion, which are, respectively: the nation of Islam, the commonalities of religions and nature; in fact, all three foundations are based on commonalities.

The Islamic Nation verse expresses the realm of believers of Islam. The commonality verse provides a basis for communication with the audience, and the Recognition verse has an anthropological point of view about the possibility of communication (Abdul Rahman 2005). However, given that in all three verses the purpose is to inform the audience and introduce them to theology, the invitation verse can govern the other three verses. The invitation verse includes both the content and the method of communication. Inspired by these four verses with a little patience, it can discuss the basis of communication under the following titles: "Islamic Nation", "Commonalities of Religions" and "Nature". In fact, the provisions of the invitation in verse 125 are interpreted with three other verses and form a basis for communication with the involved parties. Undoubtedly, intercultural communication will end in failure without a basis for communication.

\subsection{Communication in the Realm of Islamic Nation}

The verse 125 of Surah Nahl determines the direction of the invitation before advising on the invitation method. The direction of the invitation in this verse is the Way of God (sabil-i Rabbika) expressed in general terms, and it seems to be expanded and interpreted in verse 104 of Al-i-Imran: "Let there be one nation of you that shall call to righteousness, ordering honour, and forbidding dishonour. Those are the prosperous". In this verse "righteousness" is introduced as the content of the invitation. "Righteousness" in the Quran is a substitution for Paradise (Baqarah: 221), Islam (Saff: 7), Salvation (Ghafir: 41), faith (Ghafir: 10), the charity (Muhammad: 38), Allah (Ahzab: 46; Nur: 51), the guidance (Kahf: 57), and the book of Allah (Al-iImran: 23). And has companionship relation to Allah (Naml: 27), wisdom (Baqarah: 269), the Hereafter (Nisa: 77), Piety (A'raf: 26, 169; Yusuf: 57), charity (Baqarah: 272), observance of Divine Haram (Hajj: 30), repentance (Tawbah: 74), prayer (Jumua: 9), jihad (Saff: 11), fasting (Baqarah: 184), and... As it will be explained further, all these examples will be possible by inviting one to Islam.

Due to having all the previous sharīa characteristics, Islam has a kind of comprehensiveness and inclusiveness because of which it can be considered a religion in which all prophets believed and which, due to time and space requirements, could not be realized at their presence. This means that the ideals of all the Prophets and their beliefs have been this comprehensive 
religion, but there was no possibility of its realization at that time due to a lack of capacity. It is necessary to point out that there cannot be an equilibrium between the sharía. The reason for this can be expressed in two ways: first, each shari'a has been revealed in the temporal and spatial conditions and the requirements of the age, and each one has contained part of the religion of Islam, which is the first and last religion of God and the direct path towards perfection and prosperity. One cannot believe in an alignment among sharía. However, we believe that all the prophets were inclined to a comprehensive religion, but they lived in an age that, despite their beliefs, could not realize all the teachings of religions. On the other hand, Allah, has "preferred some prophets above others" (Isra: 55 ), "of these messengers, we have preferred some above others" (Baqarah: 253; Isra: 55). This superiority has also existed and fulfilled in sharía.

Secondly, all of the sharía are not at one level in terms of doctrines and propositions, and there are differences between them, which, if it doesn't cause a significant change, is an important factor for non-alignment. The last sharía in many respects is superior to all the previous shari'a.

Although Islam not only has accepted the previous shari'a as a right and retained and protected all the rights of the former nations, it has never accepted the equality with other sharía. Islam is the sharía which can only be accepted as a complete and comprehensive religion. This Quranic attitude eliminates the pluralist foundation in religion, although it accepts pluralism in sharîa as a right and a reality (Mansoori, internet).

Some people by following the verse 145 of Surah Baqarah, say: "But even if you brought those to whom the book had been given every proof, they would not accept your direction, nor would you accept theirs; nor would any of them accept the direction of the other", and they are attempting to claim that Islam and the Quran have accepted pluralism in religion. This verse points out by a blameless view to the attitude and approach of the believers of other sharía that this approach is based on the caprice, not an acceptable, reasonable and right issue (ibid.). And therefore, throughout his life, the Prophet Muhammad tried to invite people to Islam (i.e., to the truth). Motahhari (2010: XVI/84) in explaining the description of Imam Ali toward the Prophet Muhammad, calling him "tabib davvar", says: "Of course, it is obvious that he is not a physician of the body who gives the people a prescription of Bullfighting, but a psychiatric and community physician: tabib davvar bi-tibbih" (Nahj al-Balaghah:321). In the first metaphor that sees him as a physician, he wants to say that the Prophet's method was a method a physician uses in treating his patients. One of the characteristics of the physicians is having pity for the patient, as Ali said in Nahj al-Balaghah: "those who have been succeeded by God to keep away from sin, should pity upon 
the sinner patients" (ibid.: 428). The Prophet went to spiritual and moral sicknesses. Such was his work during his lifetime. In the days of the haram's months, which became immune and Arab tribes came; the Prophet used the opportunity and went among them in order to carry out the actions of Hajj as their own idolatry, when they gathered in Arafat and Mina. What was this for? (ibid.). It was not a compassionate effort unless he could invite another to the believers of Islam. The content of verses 13 to 15 of Sura Shura, emphasizing that the order based on religion has been a common practice among the people of Noah, Ibrahim, Moses, Jesus, proclaims to the Prophet Muhammad,"so invite and go straight as you are ordered, and do not follow their desires". In this case, one can say that one of the directions of the invitation is, at present, the religion of Islam.

\subsection{Communication in the Realm of Commonalities of Religions}

The Quran has continuously introduced the movements of the prophets as interactive cultures with new messages and ideas that seek to convey the messages of Allah to the audience; Messages which have the power of cultural influence. Another feature of these messages is to hesitate the compatibility of the underlying components of the opposing cultures with the real interests of human beings. This general imagination is enough to clarify this point according to which, from the Quran's perspective, cultures exposed to these movements and the influence of Quranic messages have found themselves at risk of losing their cultural identity and domination of their own cultural components. Similarly, several propositions in the Quran point to the challenges facing the interest groups in those cultures, who saw their "face" depended on the survival of the components of their cultures and the preservation of the status quo, and sought to organize the cultural confrontation of society on this basis (Salimi 2010). The Holy Quran tries to overcome this fear by focusing on the common points of religions and humans:

Say: O followers of the Book! Come to an equitable proposition between us and you that we shall not serve any but Allah and (that) we shall not associate aught with Him, and (that) some of us shall not take others for lords besides Allah; but if they turn back, then say: Bear witness that we are Muslims (Al-i-Imran: 64).

It is clear that divine religions have many commonalities. One way of communicating with the audience is the expression of commonalities. This practice reduces the distance and eliminates the state of hostility towards the audience. In other words, when two persons or two groups or two religions, 
are with each other, and when they specify their commonalities and raise the alignments, the path to mutual understanding becomes smoother (Hojjati \& Salman 2009: 32). Richardson writes: "You can look at your audience in two ways. It can emphasize your differences with others, or emphasize on common aspects. Emphasizing differences makes it difficult to establish effective communication. But considering joint aspects removes resistance and hostility" (Richardson 2002: 16).

Therefore, the most important verse from the Holy Quran on the invitation to the commonalities among believers in God is verse 64 of Sura Ali-Imran. In fact, the Quran invites everyone to understand and integrate in the sense that they act on that single word (kalimah). It is to be understood that the word that everyone speaks about is present in all the languages. So the verse has commanded the Prophet to invite the readers of the book to "monotheism" (Tabataba'i 1994: III/389).

Ayatollah Taleghani referring to verse 249 of Surah Baqarah about the war of Saul, and Goliath, accurately compares the signs in the story of the the Quran with a part from the Torah. He speaks of the adaptation of all that has been said in the holy books with the Holy Quran and criticizes the commentators for neglecting these similarities. He believes that if we remove deviations that happened over time, we will see the unity of the principles and the essence of the teachings as Buddha, Confucius, Zoroastrianism, the ruler of Chaldea, Babylon and Egypt, the prophets of the Children of Israel and the Greek rulers, each of them, calls people to accept monotheism and an endeavor for a better life. The principles of the teachings of these elders are so close to each other that some scholars have made a mistake by thinking that perhaps they were inspired by each other (Khoshmanesh 2011).

Taking this important point into consideration, when the Prophet of Islam, after the advent of Hudaybiyyah, wrote letters to the great rulers of the world, such as Mogavgas, the ruler of Egypt, and Heraclius, the ruler of the Rome, and Kasra, the king of Iran, referred to in the aforementioned verse; i.e. the important principle that is the connection of all the religions is the principle of monotheism. This shows that Islam's peacefulness is rooted in the Prophet's age (Khatib 2011: 585). This verse is in fact the essence of Surah Al-i-Imran, and the foundation of the right and infrastructure of the community of readers of the Book and the Muslims is based on monotheism (Modarresi 1986: I/580).

From the aspect of verse 64, the emphasis on common points is the basis for understanding, and any understanding can be the basis of agreement on another issue. These verses contain useful points, including: a) investigating commonalities is an effective way in attracting followers of other religions to Islam; b) if all goals are not attained, effort must be made to achieve other 
goals; c) through inviting to the truth, the emotions and feelings of the audience are being respected (Qara'ati 1995: II/91); and d) the Quran teaches Muslims that if some people were not willing to cooperate with someone in all purposes, one should try to attract their cooperation at least in part based on the common goal, and make it the basis to advance the goals (Makarem Shirazi 1985: II/450). The reason for choosing the People of the Book and the followers of the divine and monotheistic religions is that there was a common ground between Islam and them on a large scale, and the understanding was clearly possible (Amid Zanjani 2000: IV/430). Since the purpose of the conversations and interactions of Islam with the dissenters is essentially to achieve the truth and reform their ideas and thoughts, any insurrectional argument is forbidden and the servants of God are advised to say what is better: "Tell my worshipers, that they should say words that are the finest, Satan would arouse discord among them; he is the clear enemy of mankind" (Isra: 53). "Finest words" are words that are good and better in terms of containing politeness and lack of violence and false consequences (Tabataba'i 1994: XIII/199). The Quran emphasizes that in an argument with opponents, there should be a fair struggle: "Call to the path of your lord with wisdom and fine admonition. Dispute with them in the best manner" (Nahl: 126). Because the Quran seeks to expand the seed of monotheism on all lands. Thus, the Almighty God introduces logic and strong argument as the instrument of inviting to himself, along with good deeds and good behaviour, speech and, if necessary, a good struggle. In fact, this verse, with a psychological view of its audience, offers a suitable method regarding different intellectual groups. Initially, it provides the invitation by rational reasoning, then with a good preaching, because some are persuaded only by strong reasoning and some by good preaching. Therefore, the invitation form is different due to the characteristics of the audience, considering that disputation with some audiences is also a Quranic principle.

The Prophet's tradition in dealing with non-Muslims, especially the People of the Book, according to the Quranic command is on the basis of the emphasis on the commonalities. Ja'far bin Abitaleb, the Prophet's messenger to Habasheh, recited the verses of Surah Maryam and emphasized the spiritual position of Jesus and his mother (Maryam) in the presence of $\mathrm{Na}$ jashi. Mecca's polytheists opposed the writing of the name of the Prophet during the regulation of the "treaty of Hudaybiyya" and declared that they would not accept god as a monotheistic God and Muhammad as the Prophet. Therefore, the Prophet sufficed to write "In the Name of You, o Allah" instead of "In the Name of Allah, the Beneficent, the Merciful" and the name of Muhammad, son of Abdullah, instead of Mohammad, the Prophet of Allah (Waqidi 1990: 465). The study of the text of the Prophet's letters to Heraclius 
and Bishop of the Christians of Najran also indicates that the Prophet paid attention to the principle of initiating negotiations on the basis of a common ground (re: Ghazi Abarghu 1998: 210).

The motive for inviting people to monotheism is so important that when Ma'mun asked Imam if he would come or Ma'mun and followers of the religions should go to them, Imam answered: "I will come, If God wills" (Saduq 1999: 317). Imam also benefited from a controversy and scientific reasoning and comparison in the debates. He was well versed in the Gospel, and read parts of it for the Great Imam of the Christians who had come to the Imam to negotiate (ibid.: 320). Imam Reza said to the great Imam of the Christians: "O Christian man, do you accept if I bring reason from Gospel for you?" He answered: "Can I refuse what the Gospel says?" And Imam began speaking according to the Gospel (ibid.: 318).

Mohsenian Rad has carried out a heavy project of "norms in three Bibles" with the aim of extracting the common norms of the Torah, the Gospel and the Quran through a deep content analysis. For example, according to his study, the Ten Commandments of the Torah for Moses can also be found in the Bible and in the Holy Quran. Mohsenian Rad believes that the dialogue among the people about one another's religion, which could have been one of the most important areas of "intercultural communication", has not yet happened and instead a conversation of clerics of different religions has been carried out. Mohsenian finds the major hindrance in a lack of understanding resulting from a lack of a common language among the followers of different religions, and believes that in the next few decades, with the introduction of the "message market", development of artificial intelligence, discovery of methods for storing mass information in microscopic spaces and solving the problem of understanding different languages, a development will occur in the field of intercultural communication in the field of religion (Mohsenian Rad 2013). Mohsenian does not give any value to folk understanding or "simple comprehension of the text" of religion and a conversation without competitive motivation (ibid.).

\subsubsection{Messianism as an Example of Inter-religious Common Affairs}

The issue of the belief in the emergence of a universal peacemaker at the end of time is universal and does not belong to any one nation. The origin of this ancient belief, in addition to the inner urge and inner desire of every human being who naturally seeks right and justice, and the establishment of a system of peace and security around the world, are the promises of the prophets throughout the history of mankind. During the divine mission, all the great divine prophets have promised the people, as part of their mission, 
that at the end of days a great peacemaker will emerge and save peoples of the world from the cruelty of the oppressors and eradicate corruption, injustice in the whole world and give justice to the world. A brief review in the thoughts and beliefs of different nations of the world, such as ancient Egypt, India, China, Iran and Greece, and the attitude to other myths of different peoples, makes this fact quite clear that all the different peoples of the world, while having difference of opinion, beliefs and thoughts, are waiting for the promised world peacemaker. "The promised apocalypse will be approved by most religions and monotheism (and even human beings) to correct the unorganized situation and oppression governing humanity in the field of culture, economy, law and sovereignty in a completely revolutionary and abnormal way" (Rahimpour Azghadi 2009: 116). A Swedish priest, in response to the differences and commonalities between Islam and Christianity, says: "The subject of the Savior, in the view of Islam and Christianity, has many commonalities and differences. The common aspect of this view is to await the emergence of a person who reaches mankind in his longstanding desires. The manifestation of justice, the ideal society, the salvation of humanity from oppression, poverty and darkness, and the promise of a bright and peaceful life are the greatest gospel of belief in Mahdism. Today's mankind suffers from many failures and the concept as the emergence of the Savior can open a clear vision and reduce from suffering and loneliness and failures. This common concept, which exists in all religions, is a bright and sweet hope for all religions and their followers" (Interview of author with Hans-Ecko at the Mahdism Discourse Summit 2011).

\subsubsection{Communication in the Realm of Nature (Original Nature)}

Those who are referred to in the Quran to have been considered unbelievers and idolaters, are human beings and have a lot commonalities with each other irrespective of whether they are infidels or polytheists. The Quranic dialogue with them is also due to these correlations and commonalities. The guidance messages and teachings of the Quran belong to all human beings, not specific groups or tribes. The guidelines and practices of the Infallibles: and the Quran's recommendations indicate that they have always been trying to show the way of perfection to their audience. In facing disbelievers and polytheists, the Infallibles first accepted the existence of the opposite side as human beings, and addressed the disbelievers as human beings with whom they have a great deal of human commonalities, and regardless of the opinion of the audience on the matter, they would communicate with them. By accepting these common principles and human interrelationships, that cultural and intercultural dialogue get meaning. The adoption of this 
principle is in fact the presupposition of a cultural dialogue and intercultural communication.

The verse 13 of al-Hujurat reveals an anthropological point. According to this verse, "recognition" of each other is an anthropological necessity (Serjani 2011: 10).

People, we have created you from a male and a female, and made you into nations and tribes that you might know one another. The noblest of you before Allah is the most righteous of you. Allah is the knower, the aware (Hujurat: 13).

This verse is not addressed only to believers and Muslims, but to all people (al-nās) at all times and places. Therefore, communication is a natural phenomenon. Man has a tendency to connect with the beings of the universe based on his nature. The mystery of inherency of communications is the tendency of man to express his inner and express his own things. Therefore, the emergence of "language", which is the essential pillar of communication, should be considered a natural phenomenon. Of course, language is one of the manifestations of this natural tendency, and this issue has a broader meaning than mere words (Labkhandag 2011).

Mutual understanding is a basis of communication. If two people cannot understand each other, there will be no communication. A language based on words refers to the "nature" of man. Therefore, it is highly dependent on the time and space conditions, and it cannot be expected to provide a context for human communication. Individuals and communities must be equipped with another language in order to meet their natural need for a full learning at all times and places. Original nature (God-given nature) is the constant, universal, and permanent language of human beings (Javadi Amoli 2013: 40). This language, unlike the languages of different nations, is not contractual, but a developmental capital of humans whose semantic implications no-one can change. Language based on original nature, without the need for any validity, contract and approval, has the power of connecting humans (Javadi Amoli 2009: 141). Based on this common language, humans find the possibility of communication in any culture and geography. Therefore, the only language that can harmonize the world of humanity is the natural language (ibid.: 241). For this reason, "humans are collectively a real unit and enjoy a common human conscience" (Motahhari 2012: 64).

The verses of the Holy Quran referring to human nature are abundant. For example, the verses which refer to the Prophet (Ghashiya: 21-22) and the Quran as a "reminder" (Muddaththir, 49 and 54), to the religion as "Remember" (Dhariyat: 55); and the verses of the "Forgetfulness" (Hashr: 19; Tawbah: 
67); and those refer to eternal divine covenant with humans (A'raf: 172 and 173), all are about God-given nature.

The divine nature of man is not specific to a particular group or individuals. The term "al-nās", as stated in the verse, include all the people from all over the world. Therefore, natures are found in all people, although their qualities are different in terms of weakness and severity (Mesbah Yazdi 2001: 44). Even the issue of disbelief and faith in individuals is not a reason for them not to be included in this verse. Therefore, those who go out of the path of God also have this divine capital (Javadi Amoli 1999: 23).

The second nature of cultures, which observes the Appearance and superficial dimension of societies and tribes, reduces the possibility of dialogue and communication due to the difference in the natural dimension of other cultures. But the innate capacity of various cultures provides the possibility of an intercultural dialogue. This dimension of cultures, because of its universality, will provide a context for the acceleration of communication. Even cultural differences regarding the second nature of societies, if it has an attraction to other cultures and has attracted them, exists because of the original nature of the "curiosity" and the "interest in innovation" in human beings (Motahhari 1996).

Due to the innate capacity of all cultures, religion and religious culture which manifests the nature of human beings is familiar and known to them. In the commentary of verse 213 of Surah Baqarah, referring to the philosophy of sending prophets, Tabataba'i opines that the role of religion is to bring people back to the path of original nature (Tabataba'i 1994: II/168). This interpretation is in accordance with the words of Imam Ali in expressing the philosophy of "Mission" (Nahj al-Balaghah, sermon 1).

On this basis, religious culture communicates with all the people and invites them for communication. The Quran, as a religious book, despite being written in the language of a particular tribe, uses the original natural language with which humans are familiar. Hence, if the message of the $Q u$ ran reaches people, it will affect the depth of their lives, regardless of the people's skin color and race. In fact, every natural phenomenon is appropriate for man and any non-natural phenomenon is originally unpleasant to him (Javadi Amoli 2009: XII/306). Religion, which manifests the original nature of human beings, will be appealing to all human beings and communities because societies consider it to be closely related to their lives (Javadi Amoli 2007: 306). If the internal and external barriers of a society for receiving the message of religion are removed, all cultures will accept it due to the harmonious nature of religion in relation to their nature (Labkhandagh 2011).

Each religion seeks to establish communication with human beings and in order to be able to propagandize itself, it establishes its own propaganda 
system based on its specific foundations, on the basis of which the production and exchange of meaning occur. The basis of the production and exchange of meaning in Islam is the original human nature. Nature is the common aspect of people in all places and times. Therefore, it can be a communication link between all human beings in all of their geography and their life histories (Fayyaz 2007). The only language that is the factor of harmony among human beings worldwide is "original nature", a language that all people are familiar with. No-one can raise the pretext of alienation with it, because the god of nature - the creator - has protected it: "Therefore set your face to the religion purely, the upright creation upon which he originated people. There is no changing of the creation of Allah. This is the valuable religion, although most people do not know" (Rüm: 30). The meaning of the language of the Quran is to speak to the common culture of the people. Although human beings are alien to each other in terms of their literature and do not have any commonalities in ethnic and climatic cultures, in the human culture, which is the culture of a stable nature, they are united. The Quran speaks about this common culture with its audience. The Quran's mission is to nourish original nature. Therefore, the language of the Quran is familiar to all and its understanding is possible for mankind (Javadi Amoli 2009: 26-27).

Therefore, the Quran regards the invitation based on original human nature and considers its teachings consistent with pure human being nature. According to the Quran, all humans have a pure nature and the ability of accepting and recognizing the truth. The common language in intercultural communication is the original natural language, which is also universal, and Allah created all human beings with a special creation and unit nature. Insights and intuitive tendencies are not enclosed in the common nature of human beings at a specific time and place, but they can be found in all human beings, and this is the most important element in establishing communication between individuals from different cultures. Similarly, in the narrative of Imam Ali, the philosophy of the message is the resurrection of the original human nature: "Then Allah sent His Messengers and series of His prophets towards them to get them to fulfil the pledges of His creation, to recall to them His bounties..." (Nahj al-Balaghah, sermon 1; Majlisi 1984: $\mathrm{XI} / 61$ ). Using this single, fixed, public and common language, humans are in touch with each other and benefit from each other's experiences. Hence, the main goal of a cultural exchange is to achieve superior thought for a better life, guidance, the promotion of beliefs and ideas, knowledge of the experiences of others, helping one to establish and maintain peace and eliminate misunderstandings, to exchange information and everything that is effective in spiritual affairs. Imam Ali recommends to his child, Imam Hassan Mujtaba, that he should "inform from the news of the ancestors and go to the 
homes and survivors [land and culture and civilization] look at what they did and where they were from and where they went and where they landed" (Nahj al-Balaghah, Letter 31). Allah asks humans to return to their pure nature and, on the basis of it, choose a path which is closer to their nature and consistent with it, and ultimately, to be the cause of their happiness and prosperity in the world and in the Hereafter: "With all this, you are ready to accept religion and rituals that are pure from pollution and prophecies and arising from the purity of human beings that God has created them on such nature and, of course, never has any change in what God has created" (Rüm: 30).

\section{The Relationship Between Shariah and Original Nature}

Almighty Allah, through eternity and mercy, sent down the Prophets and the divine books to help mankind and release the soul from this thick pod of nature. Since man is born of the universe of nature and is born in the arms of a woman and is cultivated in the pod of nature, and his clergy and nature are also entered in this veil, as the ordinances of nature are surrounded by human beings - the more human develops in this world of nature, these rules are more dominant and as they reach the stage of infantility, their animal forces will embrace him firmly and when this darkness and oppression overcome the soul, it happens rarely that one can escape from these veils and can go through its original nature and reach the absolute perfection and the light of absolute beauty and glory. The divine commandments and verses and the orders of the great prophets are established according to the plan of original nature. All divine ordinances are divided into two types: one, the main and independent, and the other subordinate and consequential, and all the divine orders refer to these two destinations, either directly or indirectly" (Khomeini 2003: 79).

Ayatollah Javadi Amoli describes the relationship between original nature and religion as follows: "Laws of this world are a series of credit laws that come from the inside and guide man inward because they set equal to original nature; therefore, Allah considers religion as a nature; that is, the relationship between credit laws and creation (takvin) is so strong that if that creation appeared, it would turn into religious regulations, and if it were possible that the credit laws would appear in the form of Genesis, it would become nature and human reality. Therefore, these credit laws have a creational basis, which is related to the past and the future of human beings. Human beings, through these credits, build the bridge that connects to their creational backbone. This is where the paths of truths connect together. Otherwise, human based on purely credits cannot communicate with his past, and cannot communicate with his future" (Javadi Amoli 2014). 
In the interpretation of some scholars, original nature is referred to as general guidance, and there is a correlation between the knowledge obtained from it and the knowledge obtained from the revelation guidance. Because, according to the Quran, both types of guidance have a divine source. Hence, the revelation commands of Allah about justice are momentarily comprehensible through original nature. The revelation guidance helps a person to reach the "desirable". Through the revelation guidance, Allah gives man a guidance of virtue. The revelation guidance makes the people consistent in facing with unbelievers and hypocrites (Sachedina 2007: 162-173).

The essence of religion, which is in accordance with human nature (Jamshidi 2014: 69), is not a factor of difference, but it provides a way of understanding and sharing thoughts to believers. Since there is a lot of contradictions in the instances of the truth of religion and nature, Shari'a will be decisive as the manifestation of the essence of religion and original nature. According to Tabataba'i, "the idea and practice that Islam invites to, is the belief and practice that is in accordance with original human nature" (Tabataba'i 1994: XIX/207). According to verse 8 of Surah Hadid, a reference to nature follows the faith in God: "Why do not you believe in God while the Messenger (he) calls you to believe in your God, and has taken you a covenant (covenant by nature and wisdom), if you are ready to believe" (Hadid: 8); as leaving the darkness to light is possible in the light of the Holy Quran (Ibrahim: 1), the Quran itself is light (A'raf: 157) and guides with he help of its light.

\section{Summary and Conclusion}

After reviewing some of the most important topics of intercultural philosophy, we compared it to Islam's view on the intercultural communication, and concluded that the teachings observing intercultural philosophy are abundant in Islam, but these two views are not quite identical. Unlike intercultural thought, the Islamic attitude never complies with the relativity of the truth. Although intercultural thought attempts to leave the existing epistemic deadlocks and suggests communication through a dialogue among all human beings but on the basis of a mere dialogue, no solution can be offered for communication, since a dialogue without an obligation to common basis among humans is not affected. In contrast to the Islamic point of view inspired by the verses of the Holy Quran and the tradition of prophets and Imams, there are at least three foundations for communicating with mankind: Islam (which can be raised in the scope of the Islamic Nation), the common capacities of the religions as well as original human nature. All three bases tend to be oriented towards monotheism. In short, 
humanity cannot solve social and epistemic crises except with the help of the capacities of religions.

Received: October $29^{\text {th }}, 2018$.

Accepted: December $4^{\text {th }}, 2018$.

\section{References}

Abdul Rahman, Taha (2005), al-Haq al-Islami Fi Al-Ikhtelaf Al-Fekri, Beirut.

Alikhani, Ali Akbar (2013), Islam and Peaceful Life: Challenges of the Modern World for Life; Strategies and Obstacles, Tehran, Beh Afarin.

Amidi, Abdul Wahid bin Muhammad (1990), Ghurar al-Hikam va Durar al-Kalim, researcher and editor: Seyyed Mahdi Raja'i, second edition, Qom, Dar al-Kutub al-Islami.

Amid Zanjani, Abbasali (2000), Political Jurisprudence: The Rights of International Commitments and Diplomacy in Islam, Tehran. Samt.

Banki, Farzin (2013), "Introduction to Intercultural Discourse”, in: Mosleh (ed.), Intercultural Philosophy and Contemporary World, Tehran, Hekmat.

Bolkhari, Hassan (2013), "Intercultural Insight in Criticism", in: Mosleh (ed.), Intercultural Philosophy and Contemporary World, Tehran, Hekmat.

Fayyaz, Ibrahim (2007), "Islamic Perspective on Communications and Media", in: Javadi Yeganeh, M. R. \& Abdollahian, H. (ed.), Religion and Media, Tehran, Radio Research Center.

Ghazi Abarghu (1998), Rafiaddin Ishaq bin Mohammad Hamedani, Sirate Rasul-Allah, vol. 3, research by Asghar Mahdavi, Tehran, Kharazmi.

Hojjati, S. M. B. \& Salman, B. (2009), "The symbiosis of monotheistic religions from the point of view of the Quran and Traditions", Religious Research Journal 13: 29-50.

Interview of author with Hans Echo at the Mahdaviyat Dialogue Summit, 2011. Jamshidi, Mehdi (2014), Cultural Theory of Professor Motahhari, Tehran, Publishing Organization of the Research Institute of Islamic Culture and Thought.

Javadi Amoli, Abdullah (1999), Theoretical and practical wisdom in Nahj alBalaghah, Qom, Isra.

Javadi Amoli, Abdullah (2007), The origin of thought, $2^{\text {nd }}$ edition, Qom, Isra.

Javadi Amoli, Abdullah (2009), International Relations in Islam, Qom, Isra.

Javadi Amoli, Abdullah (2013), Interpretation of Human to Human, $7^{\text {th }}$ edition, Qom, Isra.

Javadi Amoli, Abdullah (2014), "A Commentary on the Treatise of Al-Walaya by Allameh Tabataba'i", Mirath Javidan 2 (2).

Khanmohammadi, Karim (2011), "Ibn Khaldun and Habermas's Communication thought", Din and Resaneh 4: 52-68. 
Khatib, Abdul Karim (2011), Tafsir al-Qoran bil-Quran, Cairo, Dar al-Fekr.

Khomeini, Seyyed Ruhollah (2003), A Description of the Hadith of Intelligence and ignorance group, $8^{\text {th }}$ edition, Tehran, Institute for the Setting up and Publishing of Imam Khomeini Works, Oruj Publishing.

Khoshmanesh, Abolfazl (2011), "The Inter-Religious and Intercultural Perspective in the Interpretation from the Quran", Ketab-e Qayyem 4: 141-166.

Labkhandagh, Mohsen (2011), “The Implications of Nature's Theory in Cultural Theory", Marifate farhangi ejtemai 3 (1): 55-80.

Majlisi, Mohammad Baqir (1984), Bihar al-Anvar, Beirut, Al-Wafa Institute.

Makarem Shirazi, Naser (1985), Tafsir Nemooneh, Tehran, Dar al-Kotob Al-Eslamiye.

Mall, Ram Adhar (2000), Intercultural Philosophy, Lanham, Rowman \& Littlefield.

Mansoori, Khalil, "Symbiosis and Pluralism in Sharia", (internet), available on http://www.maarefquran.org/index.php/page, view Article/Link ID, 3650. (visited: 2014).

Mesbah Yazdi, Mohammad Tagi (2001), Amuzeshe Aqaed, Tehran, International press.

Modarresi, Mohammad Tagi (1986), Min Huda Al-Quran, Beirut, Dar al-Huda.

Mohsenian Rad, Mahdi (2013), Norms in three scared books, Qom, Adyan press.

Mosleh, Ali Asghar (2007), "The Origin of Insight and Intercultural Philosophy", Research on the Philosophy of Religion 10: 67-82.

Motahhari, Morteza (1996), Nature, $8^{\text {th }}$ edition, Tehran, Sadra.

Motahhari, Morteza (2010), Collection of works, vol. 16, Qom, Sadra.

Motahhari, Morteza (2012), Man in the Quran, Qom, Sadra.

Qara'ati, Mohsen (1995), Tafsir Noor, Qom, Dar Rahe Haq Institute.

Rahimpour Azghadi, Hasan (2009), Tolerance, not through Pluralism, $6^{\text {th }}$ edition, Tehran, Tarh-e-Farda.

Razavirad, Mohammad, "Finding and Hidden of the Intercultural Thought", (internet), available on http://www.interculturalstudies.ir/fa/?p=217 (visited on March $17^{\text {th }}$ 2013).

Richardson, Jerry (2002), The Magic of Rapport, translated by Mehdi Gharachedaghi, $7^{\text {th }}$ edition, Tehran, Peykan Publishing.

Sachedina, Abdulaziz (2007), The Foundations of Social Symbiosis in Islam, translated by Seyyed Mohammad Reza Hashemi, Qom, Adyan Publication.

Saduq, Mohammad bin Ali (1999), Uyun Akhbar Al-Rida, vol. 7, Tehran, Jahan press.

Salimi, Ali (2010), "Themes of a theory of intercultural communication in the teachings of the Quran", Islam and social sciences, autumn and winter: 7-38.

Serjani, Ragheb (2011), Al-Moshtarak Al-Ensani, Cairo, Institute of publishing and distributing and translating. 
Shah Hoseini, Yousef, “Movlana’s Intercultural Approach” (internet), available on ttp://www.ettelaathekmatvamarefat.com/new/index.php?option=com_content\&view=article\&id=893:1392-12-27-08-19-14\&catid=54:mag12\&Itemid=64 (visited: 2014).

Tabataba'i, Seyyed Mohammad Hussein (1994), Tafsir Al-Mizan, translated by Mohammad Bagher Mousavi Hamedani, Allameh Tabataba'i Scientific and intellectual Foundation.

Waqidi, Mohammad bin Omar (1990), Kitab al-Tarikh va-al-Maghazi: The History of the Prophet's Wars, translated by Mahmoud Mahdavi Damghani, $2^{\text {nd }}$ edition, Tehran, Markaze Neshre Daneshahi.

Zamakhshari, Mahmud ibn Umar (1987), Al-Kashshaf, Beirut, Dar al-kutub. 